IRISH CONSUMERS' PERCEPTION OF CHINESE BRANDS AND HOW TO

IMPROVE THE "MADE IN CHINA" IMAGE

Xiaoxia Wang

Dublin City University Business School

Glasnevin, Dublin 9

Ireland

Telephone: +353860856786

Fax: + 35317005446

Email: xiaoxia.wang22@mail.dcu.ie

Yuhui Gao*

Marketing Group

Dublin City University Business School

Glasnevin, Dublin 9

Ireland

Telephone: +3531 7006936

Fax: + 35317005446

E-mail: Yuhui.Gao@dcu.ie

* Corresponding author

Please cite as Wang, X. \& Gao, Y. (2010). Irish consermer" perception of Chinese brands and how to improve the "Made in China" image. Journal of Asia Business Studies, 4(2), 80-85. 


\title{
IRISH CONSUMERS' PERCEPTION OF CHINESE BRANDS AND HOW TO IMPROVE THE "MADE IN CHINA" IMAGE
}

\begin{abstract}
The Chinese government launched the "going abroad" policy in 2001 to encourage Chinese companies to invest and create Chinese brands in international markets. However, the perceptions of Chinese brands among Western consumers have been shown to be consistently low, especially amongst European consumers. This research aims to investigate the Irish consumers' perception of Chinese brands and how to improve the "Made in China" image. This paper also investigates consumers' perceptions and attitudes when making purchase decisions for Chinese brands based on gender, age, and nationality. The paper provides important recommendations for Chinese companies who plan to enter the European, and more particularly, the Irish market.
\end{abstract}

\section{KEYWORDS}

Country of Origin, "Made in China" image, Brand image, Irish consumers 


\section{IRISH CONSUMERS' PERCEPTION OF CHINESE BRANDS AND HOW TO IMPROVE THE "MADE IN CHINA" IMAGE}

\section{INTRODUCTION}

Consumers are being presented with an increasing choice of products from many different countries. Since the 1960s, many empirical studies have been conducted to assess consumer evaluations of products (Niss 1996). Most of these studies show that national image is an important factor for both consumers and industry when they evaluate products (Bilkey and Nes, 1982). For example, as Chinese companies have expanded into the international market, they have thrived in global industries. Yet this success is largely due to excellent manufacturing, low cost, and high economies of scale. It is not due to brand image. The lack of a brand image and experience in the global market constitutes a problem for future development (Zeng and Williamson, 2003). The "Made in China" tag is a powerful brand image associated with watches, socks, shoes, toys, pens, and Christmas decorations in most foreign consumers' minds. After 2001, the "going abroad" policy encouraged Chinese companies to invest and create Chinese brands in overseas industries, such as in consumer goods (Lenovo (computer), TCL (television), and Haier (appliances)) and financial services: Bank of China; China Life, and China Merchants Bank. Take the success of Lenovo for example, it has become China's No. 1 computer manufacturer since it bought 
IBM's PC business. Lenovo is fast gaining global recognition and has emerged as a truly global player (Fan 2006; Bremner 2006).

Despite the success of many famous Chinese brands, however, there is still a lack of awareness of Chinese-owned global brands in developed countries. For instance, European consumers, particularly Irish consumers, are not aware of Chinese-owned brands. They only associate China with the "Made in China" label. These perceptions about the country of origin of a product can influence consumers' attitudes and behaviour towards a brand. Temporal (2005) claims that if they are to succeed internationally, Asian companies have to overcome significant problems concerning perceptions of quality on the part of global consumers and other matters that pertain to the country of origin and the brand. In order for a country's businesses to gain a competitive advantage in world markets, it is necessary to manage the national image strategically.

This paper aims to investigate the following research questions: 1) How do Irish consumers perceive Chinese brands? and 2) How can the "Made in China" image be improved? The paper first reviews the literature on Country of Origin (COO) and brand image. The paper presents numerous preliminary findings based on in-depth interviews and survey data collected from 88 consumers. The last section concludes and offers recommendations for Chinese companies. 


\section{THERETICAL BACKGROUND}

\section{Country of Origin (COO) and its Effect}

The Country of Origin (COO) is defined as "the country which a consumer associates with a certain product or brand as being its source, regardless of where the product is actually produced" (Jaffe and Nebenzahl, 2001, p27). In the literature, this concept is expressed using many different terms: 'country of origin', 'country image', 'made-in country image', and 'origin country image'. An image of a country is defined as "the sum of all those emotional and aesthetic qualities such as experience, beliefs, ideas, recollections and impressions that a person has of a country" (Kotler et al.1993, p56). In this definition, it is evident that consumers form an image of $\mathrm{COO}$ based on their personal frame of reference. The COO may influence consumers in their product evaluations and a nation's general image may influence consumers' images of products and brands.

Bilkey and Nes (1982) find that the COO of a product can influence consumers' evaluation of that product. They surmise that consumers attach stereotypes to particular countries. For example, France may be viewed as a country that has competence in perfume and fashion products. The formation of an image of the $\mathrm{COO}$ may also be considered to be part of a stereotyping or classifying process that helps to simplify the making of judgments when information is lacking or when there is an overload of information (Pecotich and Ward, 2007). Consumers will rely more 
heavily on the stereotypical image of a country's products if no other information is available about the brand. This stereotype can have a positive or negative effect on the sale of goods imported into various countries. For example, Japanese wine producers would find it difficult to market their wine using the COO, whereas Japanese electronics manufacturers would have far more credibility when using the COO (Papadopoulos, 1993).

Researchers also suggest that the influence of the $\mathrm{COO}$ is stronger among the elderly, the less educated, and politically conservative consumers (Shimp and Sharma, 1987). Cordell (1992) finds that new consumers use the COO when they evaluate a product, while experts only rely on COO stereotypes when they have no, or ambiguous, information about a product. However, the perception of the $\mathrm{COO}$ also changes over time. This may occur when consumers have acquired more knowledge about the country, when the marketing of the product has improved, or when the quality of the product is enhanced. Loussaef (2001) finds that highly involved consumers are more sensitive to the $\mathrm{COO}$, but that this sensitivity diminishes as they become more familiar with the product.

\section{Single-cue and Multi-cue Models}

Chao et al. (2005) suggest that consumers use two types of models to evaluate brands and products: single-cue and multi-cue. Many earlier studies of $\mathrm{COO}$ have found that single-cue models are more common, which indicates that consumers only rely on the 
COO information when evaluating products. Bluemelhuber et al. (2007) argue that the idea that $\mathrm{COO}$ information serves as an indicator of the quality of products from a country is strongly supported by research results. It has been found that consumers use the COO to determine the overall quality of goods within a product category, such as Japanese electronics, French wines, Belgian chocolate, US action films, and German automobiles.

Multi-cue models are more realistic in the sense that consumers depend on many informational cues, such as price, product warranty, product type, and material contents of products. These issues have been found to influence the effect of the COO on consumers' evaluations of products (Chao et al. 2005). In addition, the emotions consumers feel towards a country may influence the use of the $\mathrm{COO}$ when evaluating products, even when these emotions are a consequence of historical events and are, therefore, independent of the product (Maheswaran and Chen, 2006). For example, Chinese consumers in Nanjing, which is an enduring symbol of Japanese occupation, might not purchase Japanese products because of animosity towards Japan, even though the 'Made in Japan' label generally has positive effect on the quality of certain types of products (Gabrielle et al. 1998).

\section{Brand Image and $\mathrm{COO}$}

Pecotich and Ward (2007) suggest that the brand image and COO are regarded as extrinsic cues that are related to, but not part, of the physical product, while product 
differences and product attributes are regarded as intrinsic cues that are a part of the physical product. Agbonifoh and Elimimian (1999) argue that the use of intrinsic cues by consumers has a greater influence than extrinsic cues in the assessment of the quality of products and brand image. However, for more image-based products, where the actual physical differences are hard to see, the use of the brand image as an extrinsic cue becomes more important (Holbrook et al. 1986). The brand acts as a factor that can help the consumer to group all the information. The concept that the consumer then has of the product is a summary construct, due to "information chunking" (Han 1989; Audhesh et al. 2003). In fact, the summary construct suggests that people recode and abstract individual elements of information into higher-order units around the brand, because chunks of information are easier to store in and retrieve from long-term memory. Olson (1977) argues that consumers use other extrinsic cues, such as price or $\mathrm{COO}$, less, because the information contained in the brand name is more useful. A familiar and emotional brand is a powerful cue that may even overcome the COO effect (Hong et al. 2002).

Therefore, brand image is a crucial factor in determining the emotional impact that a brand has on consumers as a result of their perceptions of brand attributes. Roll (2006) suggests that branding involves the entire sum of business elements, especially in Asian brands. It has been suggested that to build a strong brand image, international companies have to consider factors such as trust, emotion, and passion (Fournier 1998; Escalas and Bettman 2005; Shugan 2005; Ballantyne et al 2006). 


\section{METHODOLOGY}

\section{Research Design and Data Collection}

The study was designed in two interrelated stages. The first stage was primary research, in which in-depth interviews were conducted in order to determine informants' experience, motivations, attitudes, and behaviour. This information also enabled the construction of the quantitative survey. The second stage was conclusive research that involved the implementation of the quantitative survey.

In the first stage, non-probability was the chosen sampling method. Informants were selected with the express purpose of maximizing the chances of uncovering insights into the relationship between country image and brand (Erlandson et al. 1993). In-depth interviews were conducted with three Irish women who were in different life situations. The informants were interviewed in their homes for approximately one hour. The choice of using female interviewees was based on previous research which suggests that women exhibit stronger interpersonal relationships and tend to give more detailed information about how they perceive a brand (Guest 1964; Sherrod 1989; Fournier 1998). Differences in age allowed us to pay attention to socio-cultural factors that drive relationship behaviour in the interpersonal domain (Fournier, 1998). In the second stage, quantitative surveys were administered to 88 consumers in a shopping centre in Dublin. Non-probability convenience was chosen as the sampling 
method because the chances of achieving a good response rate are high (Bryman, 2004). Informed consent was given by each informant.

\section{PRELIMINARY FINDINGS AND ANALYSIS}

Finding 1: The frequency analysis revealed that the COO plays an important role in the purchasing decisions of consumers. The survey found that 44 percent of respondents agreed that the $\mathrm{COO}$ affects their purchasing decisions and eight percent strongly agreed with this statement. In total, 52 percent of respondents thought that the $\mathrm{COO}$ effect is an important factor in the buying process. Hence, $\mathrm{COO}$ plays an important role in the purchasing decisions of Irish consumers. This finding is in line with Pecotich and Ward's (2007) view that COO may be considered to be part of a classifying process that helps consumers to make decisions.

Finding 2: Findings based on in-depth interviews suggested that Irish consumers use multiple cues (i.e., price, product warranty, product type, material contents of products, and so on) when deciding whether or not to purchase a new product or brand. For instance, one interviewee responded that "If it is an unknown brand and I am buying a TV, the price and the warranty will have a big impact on my decision. ......However, Country of Origin would not have any barrier on my decision at all.” (Lucy, 26). 
Stone (2002) also suggests that there is an important connection between brand image and COO. However, the findings of this study initiated that a brand image is not so closely linked with the $\mathrm{COO}$ in Ireland. A brand image is strongly associated with price, quality, and product warranty. For example, one interviewee stated that "It would be the brand name first, such as the electric products, I like Bosch brand. I don't really care about the made from, for instance, Bosch may have a manufactory in China, India or any part of the world, but I care about the company name first or the brand name. I will think about the brand first, and price and warranty.” (Anna, 62).

A frequency analysis also showed that the brand name is more important to consumers than the "Made in China" label when deciding upon the quality of a product. The survey found that 68 percent of respondents considered that the brand name is a more important factor than the "Made in..." label. This result indicates that most consumers depend on the brand name when evaluating product quality and price, which supports the result of the in-depth interview that Irish consumers use multiple cues (Chao et al. 2005). Overall, the brand name is a more important factor than COO when determining product quality and price.

Finding 3: This finding is mainly concerned with the association between the image of Chinese brands and the "Made in China" label. The survey found that 54 percent of respondents agreed with the statement that "The image of Chinese brands is associated with the "Made in China" label". This finding confirms the result of the 
in-depth interview and Zeng and Williamson's (2003) findings that the "Made in China" label is still a powerful brand image in consumers' minds. Overall, the perception of Chinese brands is associated with the "Made in China" label among Irish consumers. Hence, the 'Made in China' image continues to have a big impact on the perception of Chinese brands among Irish consumers.

Finding 4: This study found that compared with the "Made in China" label, Irish consumers are less aware of Chinese brands. For instance, one interviewee responded that "I often bought cloth and products that said Made-in-China. But I have not bought Chinese brand cloth. I don't know if we have them in Ireland or not. We have cloth Made-in-China for sure......" (Mary, 49). The frequency analysis indicated that consumers are less aware of Chinese brands. The survey found that 57 percent of the respondents thought that people in Ireland are less aware of Chinese brands than of the "Made in China" label. Hence, for future development, Chinese companies would be well-advised to introduce Chinese brands into the Irish society.

Finding 5: The survey also revealed what is considered to be the most important factor of brand image. Overall, 61 percent of respondents regarded the trust factor as being more important than other factors. This result indicates that most consumers regard trust as an important factor when deciding whether or not to buy, and that Chinese brands can elicit trust among Irish consumers. This result also confirms the result of the in-depth interviews. For instance, one interviewee stated that "I suppose 
that Chinese brands should be marketed well, quality and price are going to be important elements. ..For me, I will go for the brand that I trust, unless this new Chinese laptop has more functions with good warranty and good price, then I may change my decision to buy a Chinese laptop." (Lucy, 26). So if a brand's image is to be improved in the Irish society, particularly a Chinese brand, it must convey trust.

\section{Additional Analysis Related to Gender, Age, and Nationality}

Gender: The survey asked the respondents to rank, in order of importance, the factors they use when making a decision whether or not to purchase. The Mann-Whitney U Test was conducted to test whether there were any differences between male and female consumers.

Table 1: Additional analysis by gender

\begin{tabular}{|c|c|c|c|c|c|c|c|}
\hline & \multicolumn{3}{|c|}{ Female } & \multicolumn{3}{|l|}{ Male } & \multirow{2}{*}{$\begin{array}{l}\text { P- } \\
\text { Value }\end{array}$} \\
\hline & Mean & $\mathbf{N}$ & Sd & Mean & $\mathbf{N}$ & Sd & \\
\hline 1. The COO plays a role in the & 2.60 & 53 & 1.00 & 2.83 & 36 & 1.0 & .290 \\
\hline purchase decision. & & & & & & 3 & \\
\hline $\begin{array}{l}\text { 2. The brand name is a more important } \\
\text { factor than the "made in..." label for } \\
\text { determining product quality and price. }\end{array}$ & 2.60 & 53 & 1.19 & 2.11 & 36 & .82 & .078 \\
\hline $\begin{array}{l}\text { 3. The image of Chinese brands is } \\
\text { associated with the "Made in China" } \\
\text { label. }\end{array}$ & 2.54 & 52 & .94 & 2.72 & 36 & .91 & .373 \\
\hline $\begin{array}{l}\text { 4. Chinese brands have less awareness } \\
\text { in your mind. }\end{array}$ & 2.75 & 52 & .926 & 2.39 & 36 & .90 & $.050 * *$ \\
\hline
\end{tabular}

$* * \mathrm{P}<0.05$

As Table 1 shows, only one variable, namely statement four "Chinese brands have less awareness in your mind", has a p-value of .050. This means that there is a 
significant difference between males and females $(p=0.050)$. Furthermore from the mean scores it can be seen that females (mean $=2.75$ ) have scored this variable higher than males (mean=2.39), suggesting this issue is less important to the latter. This means female consumers are more aware of Chinese brands than male consumers. For the three other variables, the p-values are above .05 , which indicates that there is no evidence to suggest that males and females differ significantly. Since the result shows female consumers are more familiar with Chinese brands than male consumers in the Irish market, Chinese companies should develop new brands to associate products with female consumers. In this way, Chinese companies can more quickly and efficiently build brand image. The result also shows that Chinese companies should concentrate more on male consumers to develop their brand image in the future.

Age: A further analysis was conducted to test for differences between consumers of different age groups. Respondents were broken into 5 age groups and the Kruskal-Wallis Test was used to test the same variables as above. The Kruskal-Wallis test result is summarized in Table 2

Table 2: Additional analysis by age

\begin{tabular}{|c|c|c|c|c|c|c|}
\hline & $<29$ & 30-39 & $40-49$ & $50-59$ & $>60$ & \\
\hline & Mean & Mean & Mean & Mean & Mean & P-Value \\
\hline $\begin{array}{l}\text { 1. Country image effect is playing a role } \\
\text { in the purchase decision. }\end{array}$ & 2.78 & 2.42 & 2.83 & 2.89 & 2.33 & .488 \\
\hline $\begin{array}{l}\text { 2. The brand name is a more important } \\
\text { factor than the "made in..." label to }\end{array}$ & 1.78 & 2.42 & 2.87 & 2.63 & 1.89 & $.014 * *$ \\
\hline
\end{tabular}


identify product quality and price.

3. The image of Chinese brands is $\begin{array}{lllllll}2.94 & 2.58 & 2.61 & 2.63 & 2.00 & .230\end{array}$ associated with "Made in China" label.

$\begin{array}{lllllll}\text { 4. Chinese brands have less awareness } & 2.33 & 2.79 & 2.83 & 2.63 & 2.11 & .279\end{array}$

in your mind.

** $\mathrm{P}<0.05$

Results in Table 2 indicate that there are significant differences for the second variable $(\mathrm{p}=.014)$ which states brand name is a more important factor than the "made in ..." label to identify product quality and price. More precisely, the under 29 age group (mean=1.78) feels that brand name is a more important factor than the other age groups. The 40-49 age group (mean=2.87), on the other hand, feels that brand name is a less important factor than the other age groups. For the three other variables, the p-values are above .05 , indicating there is no evidence to suggest significant differences among age groups. The results indicate that the youngest age group feels brand name is a more important factor than the "made in..." label to identify product quality and price. Chinese companies can introduce new brands to the younger consumer group without considering the $\mathrm{COO}$ effect in the Irish market. On the contrary, the oldest age group feels that brand names are less important than the "made in..." label to identify product quality and price. Therefore, Chinese companies should consider the $\mathrm{COO}$ effect when introducing new brands to more elderly consumers in the Irish market. 
Nationality: An additional analysis was conducted to test if there are any differences between Irish and non-Irish consumers. The Mann-Whitney U Test was performed to examine the difference between two groups (Table 3).

Table 3: Additional analysis by nationality

\begin{tabular}{|c|c|c|c|c|c|c|c|}
\hline & \multicolumn{3}{|l|}{ Irish } & \multicolumn{3}{|c|}{ Non-Irish } & \multirow{2}{*}{$\begin{array}{l}\text { P- } \\
\text { Value }\end{array}$} \\
\hline & Mean & $\mathbf{N}$ & Sd & Mean & $\mathbf{N}$ & Sd & \\
\hline $\begin{array}{l}\text { 1. Country image effect is playing a role } \\
\text { in the purchase decision. }\end{array}$ & 2.69 & 80 & 1.03 & 2.83 & 6 & .99 & .726 \\
\hline $\begin{array}{l}\text { 2. The brand name is a more important } \\
\text { factor than the "made in..." label to } \\
\text { identify product quality and price. }\end{array}$ & 2.39 & 80 & 1.09 & 2.17 & 6 & .99 & .672 \\
\hline $\begin{array}{l}\text { 3. The image of Chinese brands is } \\
\text { associated with the "Made in China" } \\
\text { label. }\end{array}$ & 2.55 & 80 & .90 & 3.50 & 6 & 1.05 & $.028 * *$ \\
\hline $\begin{array}{l}\text { 4. Chinese brands have less awareness in } \\
\text { your mind. }\end{array}$ & 2.54 & 80 & .90 & 3.17 & 6 & 1.17 & .152 \\
\hline
\end{tabular}

$* * \mathrm{P}<0.05$

As shown in Table 3, only the third variable, which states that the image of Chinese brands is associated with the "Made in China" label, has a p-value below .050. This means that there is a significant difference between Irish and non-Irish consumers $(p=.028)$. Furthermore from the mean scores it can be seen that non-Irish consumers (mean=3.50) have scored this variable higher than their Irish counterparts (mean=2.55), suggesting this issue is a less important factor to the former group. This further suggests that non-Irish consumers are familiar with the image of Chinese brands that are not associated with the "Made in China" label. On the contrary, Irish consumers are familiar with the image of Chinese brands that is associated with the "Made in China" label. The three other variables have p-values above .05 , indicating 
there is no evidence to suggest that Irish and non-Irish consumers differ significantly. The result demonstrates that Irish consumers associate Chinese brands with the "Made in China" label to a greater degree than their non-Irish counterparts. This result proves that western countries have a lack of awareness of Chinese-owned global brands. Irish consumers are especially unaware of Chinese-owned brands, only associating these brands with the "Made in China" label. To improve the image of Chinese brands among Irish consumers, Chinese companies should first improve the image of the "Made in China" label to represent a high quality standard. Second, the Chinese government should bring a wide range of national product images to Irish consumers. Third, Chinese companies can introduce Chinese-owned global brands to the Irish society.

\section{DISCUSSION}

This study investigated the perceptions of Irish consumers of Chinese brands, and investigated the "Made in China" image. The findings have extended current knowledge of Irish perceptions of Chinese brands in a number of respects. We now discuss the contributions of this research to the understanding of the image of Chinese brands among Irish consumers.

The research results provide evidence that Irish consumers associate Chinese brands with the "Made in China" label. Firstly, the majority of respondents associate the 
image of Chinese brands with the "Made in China" label. Secondly, the COO effect is more notable for consumers that associate Chinese brands with the "Made in China" label to a significant degree. Finally, consumers in Ireland are less aware of Chinese brands than their counterparts in other countries. These findings are consistent with those of previous research, which suggests that the "Made in China" label is still a powerful brand image in consumers' minds (Zeng and Williamson, 2003).

The research results show that the $\mathrm{COO}$ effect is an important factor in the buying processes of Irish consumers. More than half of the respondents consider the COO effect as playing a major role in their product choice. This finding is consistent with previous studies, which suggest that $\mathrm{COO}$ image is considered as a part of the stereotyping process that helps to simplify judgments in the buying processes (e.g., Pecotich and Ward, 2007). However, the results also differs from Liefeld's (2002) study which found that the COO effect is not an important factor in the buying processes of North American consumers. Due to geographic and the cultural differentiation, Irish consumers have different attitudes and opinions when compared to their North American peers.

Past research has determined that consumers only rely on COO information to deduce the overall quality of goods by using single-cue models (Bluemelhuber et al. 2007). However, the authors extend these findings to consider that other information also influences the evaluation of the product. The results demonstrate the importance of 
both the brand image and the $\mathrm{COO}$ effect for Irish consumers. Although it appears that the COO effect may have a greater role in the purchase decision, it also finds that brand name may have greater relevance for product price and quality evaluations.

Overall, this further highlights that Irish consumers are adopting multi-cue models to evaluate products (Chao et al. 2005).

This research contains a number of important additional results which can be used to improve the "Made in China" image in the Irish market. It suggests that specific aspects such as gender, age, and nationality may have distinct effects on the purchase process for Chinese brands. The authors reinforce the view that the age variable should be considered during product development. For example, when marketing to elderly consumers, the $\mathrm{COO}$ effect should be given more importance during brand development so that the brand image does not attach an unfavourable country image to the product. This idea reinforces Shimp and Sharma's (1987) finding that COO effect is stronger among elderly, conservative consumers. This research also proves that not all consumer age groups are using the $\mathrm{COO}$ effect to evaluate brands in the Irish market. The authors also reinforce the view that gender could have effect on the evaluation of Chinese brands. The results show that female consumers are more familiar with Chinese brands than male consumers. In addition, the findings highlight the influence of brand image on factors that include trust, emotion, and passion. The results show that trust is the most important factor when choosing a new brand. Past research shows that emotion and passion factors can also define a good brand image 
(Fournier 1998; Ballantyne et al. 2006). However, the results of this research show Chinese brands should concentrate on the trust factor, creating an essential and valuable asset when entering the Irish market.

\section{CONCLUSION AND RESEARCH LIMITATIONS}

The findings imply that Irish consumers are using multi-cue models to evaluate the product. It suggests that the $\mathrm{COO}$ effect and the brand image are important elements for Irish consumers. This "Made in China" image draws upon an existing Chinese country image in the Irish market. Since a country's image changes over time, Chinese companies would be advised to use the brand strategy even if the Irish market initially misunderstands associations with Chinese brands.

The results of this model have a number of important implications for Chinese companies, exporters, and marketers to improve the "Made in China" image and develop Chinese business in the Irish market.

Firstly, a strong brand image is more important for younger Irish consumers. When marketing to younger consumers, the $\mathrm{COO}$ effect does not impact on brand image. Therefore, Chinese companies should concentrate on the development of brand image among younger consumers without considering the $\mathrm{COO}$ effect. 
Secondly, Chinese brands have a stronger impact on female consumers. When marketing products to females in the Irish market, Chinese companies should recognize this stronger brand awareness in order to promote their brands efficiently in order to save time and cost. However, male consumers have less awareness of Chinese brands. When marketing products to this group, Chinese companies may experience a barrier to the awareness of brand image.

In the future, country image (whether positive or negative) and brand associations need to be carefully considered. The research result indicates that the $\mathrm{COO}$ effect and brand name are equally important factors affecting purchase decisions in the Irish market. Stone (2002) also finds that brand image and the COO effect have an important linkage. The brand image of goods and services should be linked to the countries in which they are originally produced as a good strategy to develop new markets. Niss (1996) suggests that using COO references give products an immediate identity and allows for faster penetration into new markets. However, if the COO effect creates a negative image of a product, it should not be linked with its brand image. Rather, the Chinese company should concentrate on the brand image as a way to avoid the $\mathrm{COO}$ effect.

Finally, the research results demonstrate trust is the most important factor when choosing a new brand. Even though Irish consumers associate Chinese brands with the "Made in China" label, there is evidence that the trusted brand phenomenon has 
the greatest role in decision-making, and so greater attention to trust needs to be considered for Irish consumers. Chinese companies should manage the trusted brand to improve their image significantly over time.

Although this research has provided some interesting insights to the understanding of Irish consumers' perception of Chinese brands and how to improve the "Made in China" image, it is important to recognise the limitations related to this research.

Firstly, the findings of the present study are based on a small sample size and convenience sampling, thus the results are limited to their generalisability and should be regarded as preliminary. Secondly, while pointing out the impacts of consumers' age, gender, and nationality on their attitudes towards Chinese brands, this paper does not specifically consider particular products or product categories. An inclusion of such factors would provide a holistic view of the influence of consumers' perception of Chinese brands. 


\section{REFERENCES}

Agbonifoh, B.A. and Elimimian, J.U. (1999), "Attitudes of developing countries towards 'country-of-origin' products in an era of multiple brands", Journal of International Consumer Marketing, Vol. 11 No. 4, p. 97.

Audhesh, P.K., Kulkarni, S. and Gopal, G. (2003), "Loyalty towards the country, the state and the service brands", Journal of Brand Management, Vol. 10 No. 3, p. 233.

Ballantyne, R., Warren, A. and Nobbs, K. (2006). "The evolution of brand choice." Journal of Brand management, 13(4/5): p. 339-352.

Bremner, B. (2006), "BW's 20 Best Chinese Brands", BusinessWeek, August 28.

Bluemelhuber, C., Carter, L. L. and Lambe, C. J. (2007), "Extending the view of brand alliance effects: An integrative examination of the role of country of origin." International Marketing Review; Volume 24;Issue 4; pp. 427-443

Bilkey, W.J and Nes, E. (1982), “Country of origin effects on product evaluations”, Journal of International Business Studies, Vol. 13 No. 1, 89-99

Bryman, A. (2004), Social Research Methods, Oxford University Press. Second edition, p.100-101

Chao, P., Wuhrer, G., et al. (2005). "Celebrity and foreign brand name as moderators of country-of-origin effects." International Journal of Advertising 24(2): 173-192.

Cordell, V. V. (1992) 'Effects of consumer preferences for foreign sourced products', Journal of International Business Studies, Vol. 23, No. 2, pp. 251-269. 
Erlandson, D. A., Edward, L. H., Barbara, L. S, and Steve, D. A. (1993), Doing Naturalistic Inquiry: A Guide to Methods, Newbury Park, CA: Sage

Fan, Y. (2006), "The globalization of Chinese brands", Marketing Intelligence \& Planning; Volume: 24 Issue: 4; p365-379.

Fournier, S. (1998). "Consumers and their brands: Developing relationship theory in consumer research.”, Journal of Consumer Research 24 (March), p343-373.

Jaffe, E. D. and Nebenzahl, I. D. (2001). "National image and Competitive Advantage", Copenhagen Business School Press. First edition. p27.

Han, C. M. (1989), “Country image: halo or summary construct?”, Journal of Marketing Research, Vol. 24, pp. 222-9.

Hong, F.C., Pecotich, A. and Schultz, C.J. (2002), "Brand name translation: language constraints, product attributes, and consumer perceptions in East and Southeast Asia”, Journal of International Marketing, Vol. 10 No. 2, p. 29.

Holbrook, M.B., Lehmann, D. and O’Shaughnessy, J. (1986), “Using versus choosing: the relationship of the consumption experience to reasons for purchasing", Journal of Marketing, Vol. 20, pp. 49-62.

Gabrielle, K. J. Ettenson, R. and Morris, M. D. (1998), “The Animosity Model of Foreign Product Purchase: An Empirical Test in the People's Republic of China," Journal of Marketing, 62 (1), 89-100.

Guest, L. P. (1964), “Brand Loyalty Revisited: A Twenty-Year Report”, Journal of Applied Psychology, Vol. 48, p. 93-97.

Kotler, P., Haider, D. H. and Rein, I. (1993) 'Marketing Places', The Free Press, New York. 
Liefeld, J. P. (2002). "Consumer Knowledge and use of country-of-origin information at the point of purchase." Journal of Consumer Behaviour Vol. 4, 2, 85-96 Henry Stewart Publications 1472-0817

Loussaef, L. (2001) 'The consumer sensitivity to the perceived national origin of (PNO) brands', in Rahtz, D. and McDonagh, P. (Eds.), 'Globalization and Equity: Macromarketing Contributions: Proceedings of the 26th Annual Macromarketing Conference', College of William and Mary, Williamsburg, Virginia, pp. 70-73.

Maheswaran, D. and Chen, Y. C. (2006). "Nation Equity: Incidental Emotions in Country-of-Origin Effects." Journal of Consumer Research 33(3): 370-376.

Niss, H (1995), "Country of origin marketing over the product life cycle, a Danish case study", European Journal of Marketing, Vol. 30 No. 3, pp 6-22

Papadopoulos, N. (1993). 'What product and country images are and are not', in Papadopoulos, N. and Heslop, L. A. (Eds.), 'Product-Country Images: Impact and Role in International Marketing', Haworth Press, London, pp. 3-38.

Pecotich, A. \& Ward, S. (2007). "Global branding, country of origin and expertise: An experimental evaluation.” International Marketing Review; Volume 24; Issue 3; 271-295

Roll, M. (2006). "Building an Asian Brand." Business Strategy Review Spring 2006: 60-64.

Sherrod, D. (1989), "The Influence of Gender on Same Sex Friendships", in Review of Personality and Social psychology, Vol. 10, Close Relationships, ed. Clyde Hendrick, Newbury Park, CA: Sage, p. 164-186

Shimp, T. A. and Sharma, S. (1987). 'Consumer ethnocentrism: Construction and validation 
of the CETSCALE', Journal of Marketing Research, Vol. 24, No. 3, pp. 280-289.

Shugan, S. M. (2005) "Brand Loyalty Programs: Are They Shams?". Marketing Science, v. 24, iss. 2, pp. 185-93

Stone, M. A. (2002). "National image and competitive advantage: the theory and practice of country-of-origin effect." Journal of Marketing Management 18(3/4): 437-439.

Temporal, P. (2005). "Branding for survival in Asia." Journal of Brand Management 12(5): 374-378.

Zeng, M. and Williamson, P. J. (2003). "The Hidden Dragons." Harvard Business Review 81(10): 92-99. 